\title{
População, grupos étnico-raciais e economia cafeeira: São Carlos, $1907^{\star}$
}

\author{
Oswaldo Mário Serra Truzzi** \\ Maria Silvia Beozzo Bassanezi***
}

\begin{abstract}
Em São Carlos, a formação de uma população estabelecida iniciou-se ainda na primeira metade do século XIX, com as primeiras fazendas mantidas a braço escravo. Em 1884, com a chegada da ferrovia, o município inseriu-se definitivamente na vigorosa economia cafeeira paulista. São Carlos acompanhou assim a transição de uma economia tocada por trabalho escravo para outra em que predominavam colonos livres, de origem europeia, sobretudo italiana. Menos de duas décadas após a abolição do cativeiro, a composição racial da população alterou-se significativamente, graças ao grande afluxo de imigrantes e, provavelmente também, ainda que em menor grau, à saída de ex-escravos do município. Esse aporte diversificado traduziu-se no levantamento censitário realizado no município em 1907, que abrangeu a compilação de informações variadas referentes a 38.642 indivíduos que então o habitavam. Este trabalho busca analisar e discutir as características demográficas e a inserção social de diferentes grupos étnico-raciais presentes na população de São Carlos nessa época. Sua relevância deriva também da ausência de levantamentos populacionais no período em questão, dadas as conhecidas deficiências do censo de 1890 e 1900 e o longo período de 34 anos de intermitência entre o levantamento populacional da província de São Paulo de 1886 e o censo nacional de 1920, este mais confiável, porém omisso quanto à cor dos indivíduos.
\end{abstract}

Palavras-chave: População. Imigrantes. Negros. Economia cafeeira. São Carlos (São Paulo). Discriminação.

\section{Introdução e relevância}

No município de São Carlos, localizado na região central do Estado de São Paulo, a formação de uma população estabelecida iniciou-se ainda na primeira metade do século XIX, com as primeiras fazendas tocadas a braço escravo. Algum gado e o cultivo da cana-de-açúcar, logo depois suplantado largamente pela lavoura cafeeira, foram as atividades estruturantes dessas primeiras propriedades. Nos anos 80 do século XIX, quando o café já predominava, o município inseriu-se definitivamente na vigorosa economia cafeeira, com a chegada da ferrovia. A facilidade desse transporte, inaugurado em 1884, viabilizava a ampliação das lavouras, não apenas escoando a produção local, mas também trazendo o imigrante

\footnotetext{
* Agradecemos a colaboração da Fundação Pró-Memória do Município de São Carlos, bem como as valiosas sugestões recebidas durante o XVI Encontro Nacional de Estudos de População, no qual este trabalho foi originalmente apresentado. ${ }^{* *}$ Doutor em Ciências Sociais (Unicamp), professor associado da UFSCar e bolsista PQ/CNPq.

*** Doutora em História e pesquisadora do Núcleo de Estudos de População - Nepo/Unicamp e bolsista PQ/CNPq.
} 
europeu, um novo elemento que marcaria profundamente o perfil demográfico do município e de grande parte do oeste paulista (TRUZZI, 2007). São Carlos acompanhou assim a transição de uma economia tocada por trabalho escravo para outra em que predominavam colonos livres, ${ }^{1}$ de origem europeia, constituindo-se demograficamente por grupos variados, que construíram um tecido social diversificado.

Esse trabalho busca analisar e discutir as características demográficas e a inserção social de diferentes grupos étnico-raciais presentes na população do município duas décadas após a abolição da escravatura.

Para tanto, foi utilizado como fonte principal o recenseamento realizado em 1907 pelas autoridades do município, em que foram arroladas as características de 38.642 indivíduos. Essa fonte, nominativa e inédita, assume grande importância para o conhecimento do perfil étnico-racial da população local em uma época na qual a imigração de massa foi mais volumosa, uma vez que os recenseamentos nacionais de 1890 e 1900 não foram bem-sucedidos, apresentando problemas e lacunas. ${ }^{2}$

Assim, lamentavelmente, para o período em que o fluxo da imigração estrangeira no Brasil foi mais intenso, não se dispõe de boas informações censitárias, indicativas da cor e da nacionalidade dos diferentes grupos. Somente em 1920 foi realizado um novo censo nacional, que arrolou a população total de São Carlos em 54.225 indivíduos, sem distingui-los, contudo, quanto à cor e ao domicílio rural ou urbano. Por essas razões, acrescidas à circunstância de serem raros os recenseamentos municipais no período, o censo de 1907 realizado em São Carlos reveste-se de grande importância para o conhecimento do perfil demográfico e da inserção socioprofissional de diferentes grupos étnico-raciais em um município em grande medida exemplar da economia cafeeira paulista do período.

\section{Motivação e estrutura do censo}

A origem do censo de 1907 - como revela ofício enviado pelo prefeito de São Carlos, Manoel Antonio de Mattos, ao presidente da Câmara dos Deputados do Estado de São Paulo - deve-se à Lei n.1.038 de $19 / 12 / 1906$, que dispunha sobre a organização municipal, promulgada pelo Dr. Jorge Tibiriçá, presidente do Estado. Segundo tal Lei (art.17, §15), era incumbência das Câmaras Municipais "levantar periodicamente as estatísticas do município, e sobretudo o recenseamento da população e o cadastro do território, para o que poderão solicitar auxílio do Estado". Muito provavelmente, esse censo visava subsidiar a Câmara Municipal de São Carlos em relação a seu artigo 7을 "O número de vereadores de cada município será fixado pelo governo, na proporção de um vereador para dois mil habitantes, não podendo, porém, ser inferior a oito e nem superior a vinte".

Diante de tal diretriz, a Câmara, então composta por oito vereadores, agiu rápido e autorizou o intendente, em 4 de fevereiro de 1907, a recensear a população municipal. Este, por sua vez, por meio da Lei municipal 126, promulgada no mesmo dia, autorizou sua efetiva realização. ${ }^{3}$

\footnotetext{
1 Livres em tese. Embora os fazendeiros de café desenvolvessem formas diversas de manutenção forçada dos colonos e suas famílias nas propriedades rurais, sobretudo em épocas de colheita do café, quando a exigência de mão de obra era maior, a mobilidade geográfica foi muito intensa (VANGELISTA, 1991).

2 Consequentemente, costuma-se utilizar o levantamento populacional realizado na Província de São Paulo em 1886, pois acredita-se que ele merece mais fé do que os dois primeiros censos da República (CAMARGO, 1981, p.21). O ano de 1886, contudo, é uma data na qual a imigração em massa para São Paulo dava seus primeiros passos. Além disso, o censo então realizado não apurou as ocupações.

${ }^{3}$ Fosse o artigo 7ㅇ․ da Lei n. 1.038 implementado, São Carlos passaria a contar então com 19 vereadores, por abrigar mais de 38 mil habitantes. Não foi, contudo, o que ocorreu, pois a aplicação de outra Lei, de número 1.103, aprovada em novembro, estipulou que o número de vereadores de cada município seria fixado pelo governo, mediante proposta das respectivas Câmaras, na proporção de um para cada 4.000 habitantes, com teto mínimo de 6 e máximo de 16. Ao mesmo tempo, a referida lei dispôs que, enquanto não houvesse recenseamento, o próprio governo estipularia o número de vereadores dos municípios e a São Carlos coube dez deles, que efetivamente assumiram seus cargos a partir de 1908. A essa altura, porém, o censo já havia sido realizado em São Carlos.
} 
Infelizmente, pouco se sabe sobre a forma como foi realizado esse levantamento, pois nenhum conjunto de instrução aos responsáveis por coletar as informações foi localizado até o momento. Esse recenseamento coletou as seguintes características de cada indivíduo da população: nome, idade, sexo, estado civil, profissão, cor e nacionalidade. Não há indicação das unidades censitárias, o que dificulta a percepção exata do chefe da família e de quais membros habitavam o mesmo domicílio. Essa informação pode ser apenas inferida pela proximidade de sobrenomes comuns, mas não é precisa e tende a ignorar os agregados. Além das variáveis mencionadas, o censo incluiu ainda duas informações binárias (sim / não) referentes a ser ou não proprietário e a saber ou não ler.

FIGURA 1

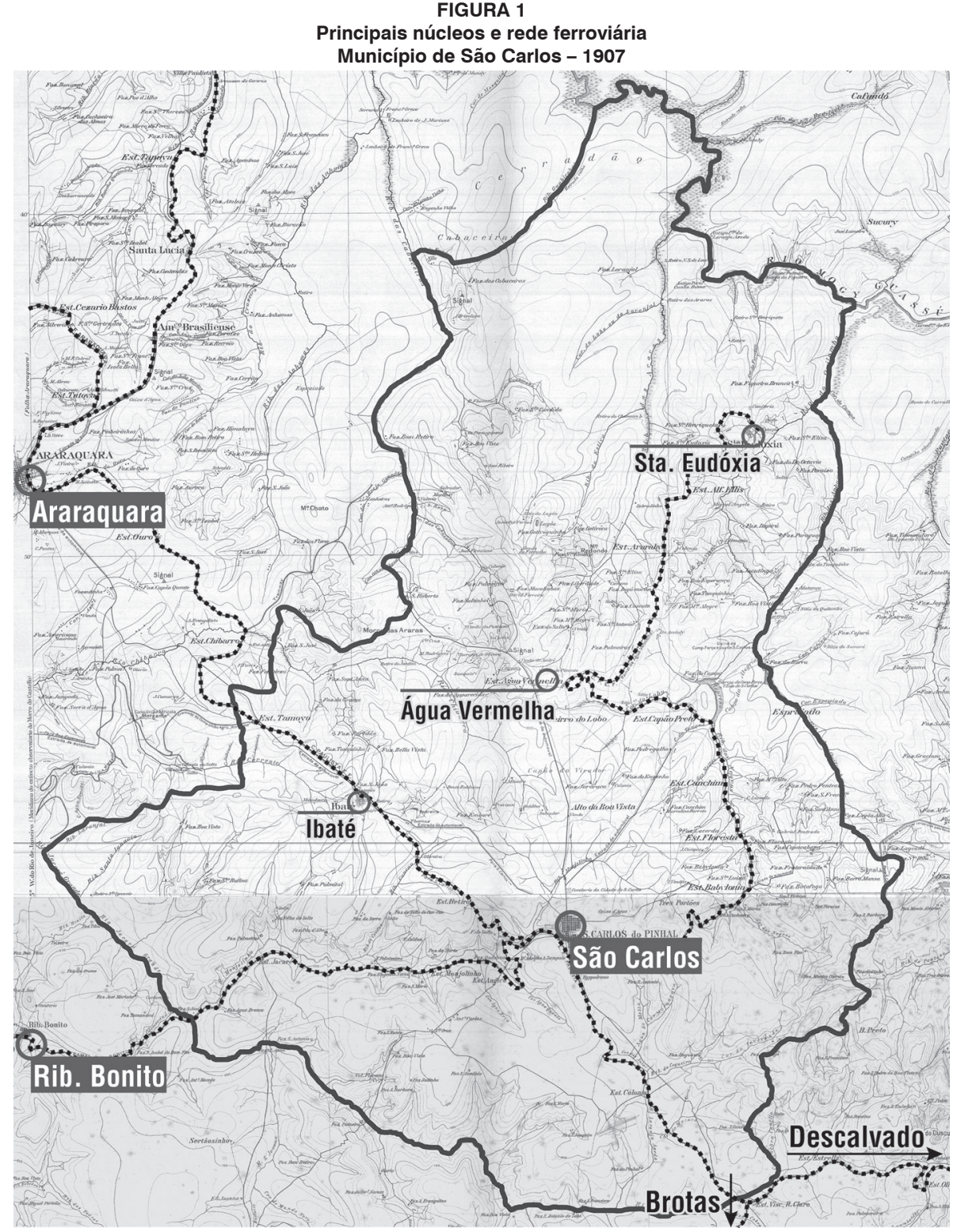

Fonte: Adaptado de Truzzi (2004). 
A compilação dos indivíduos e de suas respectivas características encontra-se ainda agrupada segundo a localização domiciliar da população no território, que se distribuía entre o próprio núcleo da cidade de São Carlos, quatro bairros adjacentes ao núcleo principal, uma área suburbana de transição e 19 regiões rurais, cada uma delas com denominações distintas, que, em geral, correspondiam ao nome de antigas fazendas, servidas pela malha ferroviária implantada no município entre 1884 e 1893. Entre essas regiões rurais, encontravam-se Ibaté ${ }^{4}$ e Santa Eudóxia, duas áreas nas quais já constavam, em 1907, as respectivas vilas.

\section{A chegada de imigrantes e seu impacto demográfico}

É provável que, depois dos índios, logo dizimados ou empurrados em direção ao interior, os primeiros habitantes da região que hoje abriga o município de São Carlos tenham sido contingentes de quilombolas, fugidos da perseguição da polícia e de fazendeiros. Estes últimos, por sua vez, vieram tanto de municípios de implantação mais antiga no Estado de São Paulo, como Itu, Piracicaba e Campinas, quanto do sul de Minas Gerais, na fronteira norte de São Paulo. Ao abrirem as primeiras fazendas na região, tiveram de importar escravos, sobretudo de regiões decadentes, nordestinas e mineiras, mesmo que a um preço mais elevado, para suprir a carência crônica de mão de obra, já que o tráfico negreiro havia sido extinto desde 1854. Com o prenúncio da abolição, esses fazendeiros passaram a importar imigrantes europeus para substituir os escravos nas lides rurais. Vieram também, ainda que em menor proporção, famílias mineiras e nordestinas, estas fugidas das secas, que buscavam se inserir na economia cafeeira em expansão (TRUZZI, 2007).

Na década final do século XIX, o município de São Carlos foi, por alguns anos, o maior receptor de imigrantes do interior paulista, recebendo diretamente da Hospedaria de Imigrantes de São Paulo, entre 1893 e 1907,5 26.918 imigrantes segundo as estatísticas da época. Nem todos aí permaneceram, assim como imigrantes que originalmente foram enviados a outros locais acabaram por se dirigir e se fixar em São Carlos, "uma das melhores lavouras do Estado de São Paulo", segundo o Relatório da Secretaria de Agricultura, Commercio e Obras Públicas do Estado de São Paulo de 1894.

A Tabela 1 mostra a evolução dos contingentes populacionais presentes no município no decorrer dos 21 anos que separam os dois levantamentos populacionais de 1886 e 1907.

Menos de duas décadas após a abolição do cativeiro, a população de São Carlos, que entre 1886 e 1907 mais do que duplicou, teve sua composição racial alterada significativamente, graças ao grande afluxo de imigrantes europeus e, provavelmente também, ainda que em bem menor grau, à saída de ex-escravos do município. Mesmo

TABELA 1

Distribuição da população, por nacionalidade e categorias raciais Município de São Carlos - 1886-1907

\begin{tabular}{|c|c|c|c|c|c|c|c|c|c|c|c|c|c|c|}
\hline \multirow[t]{2}{*}{ Anos } & \multicolumn{2}{|c|}{$\begin{array}{l}\text { Brasileiros } \\
\text { brancos }\end{array}$} & \multicolumn{2}{|c|}{$\begin{array}{c}\text { Estrangeiros } \\
\text { brancos }\end{array}$} & \multicolumn{2}{|c|}{ Caboclos } & \multicolumn{2}{|c|}{ Pardos } & \multicolumn{2}{|c|}{ Mulatos } & \multicolumn{2}{|c|}{ Pretos } & \multicolumn{2}{|c|}{ Total } \\
\hline & N. abs. & $\%$ & N. abs. & $\%$ & N. abs. & $\%$ & N. abs. & $\%$ & N. abs. & $\%$ & N. abs. & $\%$ & N. abs. & $\%$ \\
\hline 1886 & 5.209 & 32,3 & 2.039 & 12,7 & 2.906 & 18,0 & 1.957 & 12,2 & - & - & 3.993 & 24,8 & 16.104 & 100,0 \\
\hline 1907 & 18.568 & 48,1 & 15.258 & 39,4 & - & - & - & - & 1.001 & 2,6 & 3.815 & 9,9 & 38.642 & 100,0 \\
\hline
\end{tabular}

Fonte: São Paulo (1888); Recenseamento de 1907, São Carlos.

\footnotetext{
${ }^{4}$ Itabé desmembrou-se de São Carlos em 1953, enquanto a Vila de Santa Eudóxia permanece até hoje como um dos distritos de São Carlos, afastada cerca de $30 \mathrm{Km}$ de seu núcleo urbano. O outro distrito hoje existente, de Água Vermelha, foi criado em 1948.

5 Exceto 1896.
} 
que as categorias raciais não coincidam exatamente, é possível comparar as cifras disponíveis em 1886 (quando, dos 16.104 indivíduos que habitavam o município, 37\% foram arrolados como pretos ou pardos) com as do censo municipal de 1907 (em que pretos e mulatos não ultrapassavam um oitavo da população do município). Os caboclos, presentes em 1886 - quando o contato com a população nativa era ainda recente na própria região e presente em áreas mais ermas, a oeste do território paulista - foram subsumidos em 1907 como brancos ou mulatos, dependendo provavelmente da cor e também da posição social de cada indivíduo. O mesmo deve ter ocorrido com a categoria pardo, um atributo que, em épocas próximas à abolição, serviu também para designar, em algumas áreas do país, a condição de libertos (MATTOS, 1998).

Dos 5.950 indivíduos arrolados como pretos ou pardos em 1886, mais da metade (2.982) permanecia sob o jugo da escravidão, 1.277 foram identificados como ingênuos, filhos livres de mulher escrava, decorrentes da aplicação da Lei do Ventre Livre de 1871, enquanto os 1.681 restantes correspondiam aos libertos ou indivíduos já nascidos livres e classificados como pretos ou pardos. De qualquer modo, apenas dois anos antes da abolição, é possível estimar que o percentual de pretos ou pardos, ainda escravizados ou pelo menos nascidos em famílias de escravos, era no mínimo de $80 \%$ em São Carlos.
Essa população perdeu participação relativa, sobretudo com a chegada dos estrangeiros, que, em 1886, respondiam por $12,7 \%$ da população (mais da metade já era italiana), aumentando para 39,4\% em 1907 (quase três quartos dos estrangeiros eram italianos), mais do que setuplicando seu contingente em termos absolutos. Além disso, a população branca foi também incrementada pelo afluxo de brasileiros brancos (cujo volume absoluto mais do que triplicou), que acorreram ao município atraídos pela prosperidade de suas lavouras.

O impacto da imigração internacional também pode ser observado na estrutura e dinâmica populacional. A razão de sexo declinou e a população rejuvenesceu no período. Em 1907, havia 109 homens para cada 100 mulheres no conjunto da população, uma razão bem menor do que a verificada em 1886 (de 122 para 100), provavelmente graças à imigração familiar e à menor presença relativa de negros na população. Em 1886, 42,9\% da população possuía até 15 anos de idade; em 1907, $46,3 \%$ tinham até 14 anos.

No tocante aos eventos vitais, as diferenças entre as duas épocas são também bastante relevantes. Comparando-se as médias de nascimentos, casamentos e óbitos dos anos 1882-83, 1883-84 e 1885-86 com as de 1905, 1906 e 1907, 6 obtêm-se os resultados apresentados na Tabela 2.

No período, aumentou a proporção de filhos legítimos entre os nascidos vivos,

TABELA 2

Aspectos da dinâmica populacional

Município de São Carlos - 1886-1907

\begin{tabular}{lcc}
\hline Variáveis & 1886 & 1907 \\
\hline Legitimidade (\% de filhos legítimos entre nascidos vivos) & 82,8 & 97,8 \\
Taxa bruta de natalidade (nascidos vivos / total da população X 1000) & 38,3 & 48,2 \\
Taxa geral de fecundidade (nascidos vivos / total de mulheres entre 15 e 49 anos X 1000) & $\ldots$ & 224 \\
Taxa bruta de nupcialidade (casamentos por mil habitantes) & 6,4 & 7,6 \\
Taxa bruta de mortalidade (óbitos por mil habitantes) & 25,3 & 20,2 \\
\hline
\end{tabular}

Fonte: São Paulo (1888; 1905; 1906; 1907; 1908); Recenseamento de 1907, São Carlos.

(...) Dado não disponível.

\footnotetext{
${ }^{6}$ A rigor, esses anos deveriam ser contados de julho a junho, como no período anterior, mas essa informação não se encontra disponível. Em todo caso, esses dados permitem uma aproximação, mesmo que bruta, das transformações ocorridas no período.
} 
assim como as taxas brutas de natalidade e nupcialidade em função da entrada de imigrantes no município. A taxa de mortalidade, por sua vez, diminuiu. Em São Carlos, como em outras áreas cafeeiras, as taxas de morbi-mortalidade sofreram o impacto das políticas de saúde implementadas pelo governo paulista (RIBEIRO, 1993; TELAROLLI Jr., 1997). Estas estiveram, entre o final do século XIX e início do XX, subordinadas aos interesses da cafeicultura, concentrando suas ações no sentido de controlar a proliferação de epidemias e diminuir a ocorrência de endemias que afetavam os trabalhadores do café. Entre 1895 e 1898, por exemplo, São Carlos foi seriamente afetado por surtos de epidemia de febre amarela, que produziram muitas vítimas, tornando a cidade praticamente deserta entre os meses de novembro e abril, quando as temperaturas maiores aguçavam o problema (MONSMA; TRUZZI; CONCEIÇÃO, 2003; JUNQUEIRA, 2004).

As informações disponíveis nos Anuários Demógrafo-sanitários do Estado de São Paulo, da época, trazem o número de nascimentos por nacionalidade dos pais, sem discriminar se a palavra pais refere-se a ambos, pai e mãe, ou apenas ao pai. Se for levado em conta que havia uma forte homogamia matrimonial por nacionalidade no período (TRUZZI, 2007b), como mostram as estatísticas, é possível deduzir que o aumento da taxa geral de fecundidade, no período, tenha sido influenciado, sobretudo, pela fecundidade de mães estrangeiras.

Considerando-se o número de nascidos vivos segundo a nacionalidade dos pais e o de mulheres estrangeiras e 0 de mulheres brasileiras entre 15 e 49 anos, separadamente, chega-se a uma taxa bruta de fecundidade bastante elevada para as estrangeiras (276 nascidos vivos por 1.000 mulheres) e menor para as brasileiras (150 por 1.000). É preciso, no entanto, sublinhar que, entre os brasileiros, o registro civil dos eventos vitais ainda não havia se tornado um hábito como já o era entre os estrangeiros, mais acostumados à formalização desses eventos. Portanto, é possível que tenha havido um sub-registro de nascidos vivos de mulheres brasileiras.

Por outro lado, havia ainda o componente da estrutura etária mais velha das estrangeiras a interferir em tais taxas. $\mathrm{Na}$ ausência de dados mais sólidos, as taxas aqui calculadas são um indicativo de que a

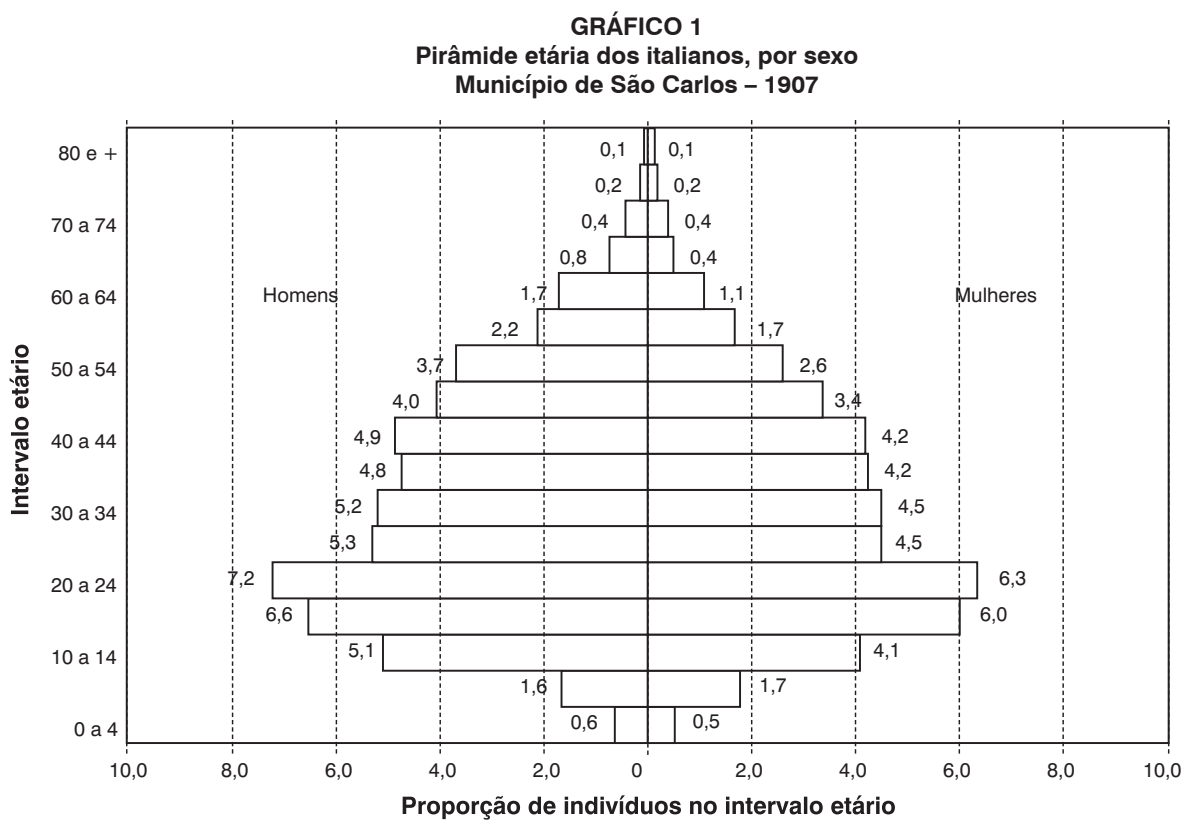

Fonte: Recenseamento de 1907, São Carlos. 
imigração impactou também no sentido de ampliar o crescimento vegetativo e aumentar a legitimidade, em São Carlos e no Estado de São Paulo como um todo.

O Gráfico 1 exibe a pirâmide etária de italianos residentes em São Carlos em 1907, tipicamente conformada por uma população imigrante: mais homens do que mulheres, poucas crianças e uma evidente predominância de pessoas em idades produtivas e reprodutivas.

Portanto, com a chegada dos imigrantes, principalmente a partir da última década do século XIX, abriu-se um novo panorama demográfico. Se a distribuição por nacionalidades registra que os brasileiros constituíam mais de $60 \%$ da população do município, não se pode esquecer, contudo, que entre estes brasileiros encontram-se arrolados muitos filhos de estrangeiros nascidos no Brasil, em função da norma vigente do jus solis.

Entre os imigrantes estrangeiros, os italianos predominaram amplamente, atingindo quase $30 \%$ da população do município. Em seu conjunto, eram procedentes tanto de regiões do norte da Itália, como o Vêneto, quanto do sul, como a Calábria (TRUZZI, 2007b).

Mas não foram apenas brasileiros e italianos que moldaram a população. Afora tais grupos majoritários, os $10 \%$ restantes da população do município abrigavam espanhóis, portugueses, alemães, turcos (na verdade sírios e libaneses) e indivíduos de outros grupos numericamente não tão expressivos.

\section{Distribuição da população}

É sempre sujeita a controvérsias a demarcação entre áreas urbanas e rurais. No agrupamento utilizado pelo censo, há áreas nitidamente rurais, outras claramente urbanas e outras zonas de transição entre uma e outra. Na necessidade de se adotar um critério, considera-se aqui área urbana o próprio núcleo urbano de São Carlos, acrescido dos quatro bairros destacados pelo censo (Vila Nery, Vila Izabel, Vila Pureza e Botafogo). As outras áreas, que incluem as regiões de propriedades rurais, mais os subúrbios da cidade e as vilas de Ibaté e Santa Eudóxia, foram agrupa-

\section{GRÁFICO 2}

Distribuição da população, por nacionalidade e cor Município de São Carlos - 1907

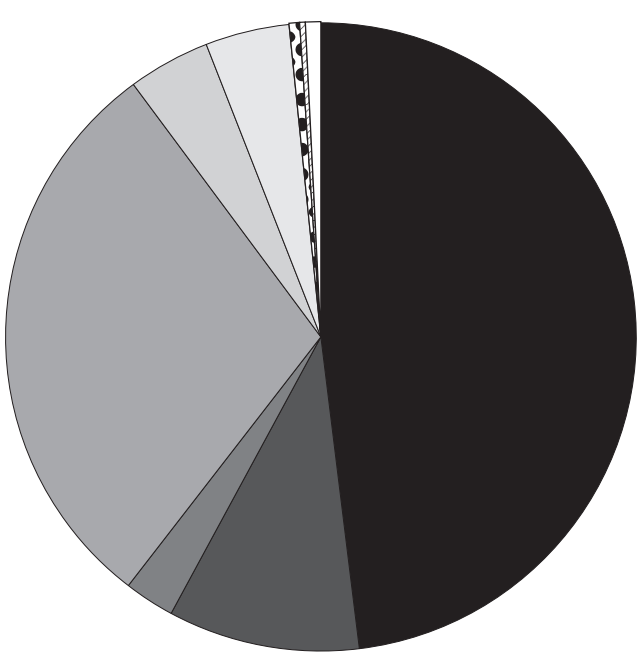

Fonte: Recenseamento de 1907, São Carlos.

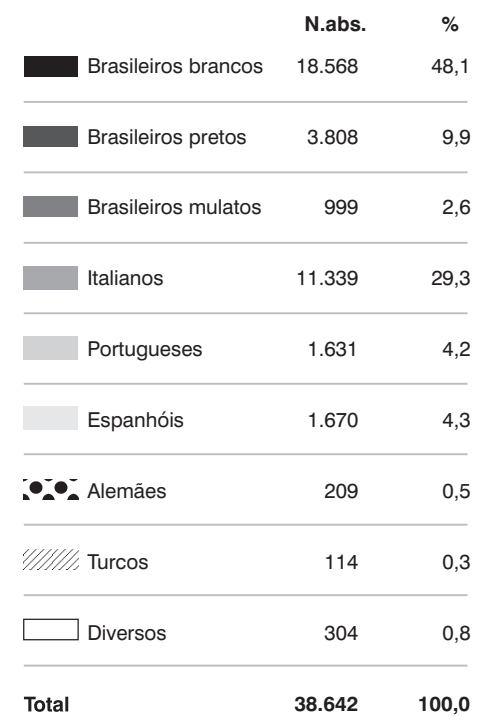




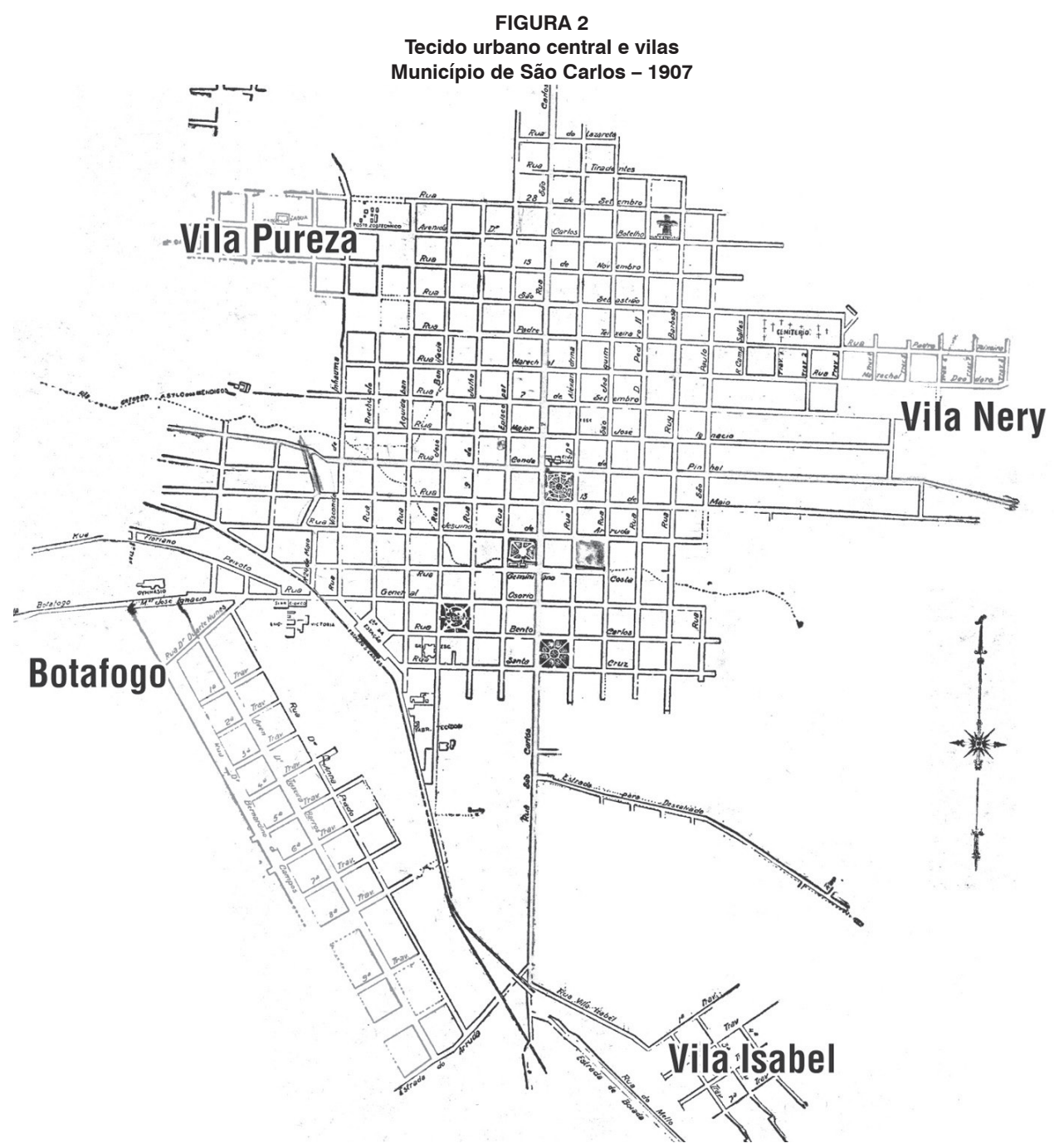

Fonte: Adaptado de São Paulo. Secretaria da Agricultura, Indústria e Comércio. Instituto Geográfico e Geológico. Serviço de Topografia e Limites. Planta da Cidade de São Carlos, 1938.

das como rurais por se considerar que a influência desse meio era preponderante nessas áreas.

Adotando-se esse critério, conclui-se que, em 1907, 77,8\% da população habitava o meio rural (30.058 indivíduos), enquanto a população urbana perfazia $22,2 \%$ do total (8.584 pessoas). Mesmo considerando-se os subúrbios área urbana, pode-se afirmar que mais de três quartos da população do município residiam em áreas rurais. Os brasileiros, incluindo os filhos de estrangeiros, constituíam mais de $60 \%$ da população do município. A presença de brasileiros era mais marcante no meio urbano (quase $70 \%$ ) do que no rural (58\%).

Fora do núcleo urbano assim considerado, os bairros rurais mais populosos (mais de 2.000 habitantes) eram Ibaté, Água Vermelha, Santa Eudóxia, Babylonia, Monjolinho e Jacaré. Dos habitantes de lbaté e Santa Eudóxia, viviam nas vilas, fora das fazendas, $10,7 \%$ e $25,7 \%$, respectivamente. A distribuição da população recenseada segundo a situação domiciliar é apresentada na Tabela 3. 
TABELA 3

Distribuição da população, segundo localidades

Município de São Carlos - 1907

\begin{tabular}{|c|c|c|}
\hline Localidades & N. abs. & $\%$ \\
\hline Total município & 38.642 & 100,0 \\
\hline Rural & 30.058 & 77,8 \\
\hline Ibaté villa & 652 & 1,7 \\
\hline Ibaté fazendas & 5.433 & 14,1 \\
\hline Jacaré & 2.010 & 5,2 \\
\hline Monjolinho & 2.234 & 5,8 \\
\hline Água Quente & 453 & 1,2 \\
\hline Água Fria & 317 & 0,8 \\
\hline Corta Rabicho & 580 & 1,5 \\
\hline Colônia & 280 & 0,7 \\
\hline Lobo & 368 & 1,0 \\
\hline Pinhal & 1.302 & 3,4 \\
\hline Visconde Rio Claro & 570 & 1,5 \\
\hline Babylonia & 2.295 & 5,9 \\
\hline Floresta & 1.848 & 4,8 \\
\hline Canchim & 292 & 0,8 \\
\hline Capão Preto & 1.124 & 2,9 \\
\hline Água Vermelha & 5.411 & 14,0 \\
\hline Fortaleza & 218 & 0,6 \\
\hline Cancan & 690 & 1,8 \\
\hline Ararahy & 750 & 1,9 \\
\hline Santa Eudóxia fazendas & 1.869 & 4,8 \\
\hline Santa Eudóxia villa & 646 & 1,7 \\
\hline Subúrbios & 716 & 1,9 \\
\hline Urbano & 8.584 & 22,2 \\
\hline Villa Izabel & 163 & 0,4 \\
\hline Botafogo & 95 & 0,2 \\
\hline São Carlos cidade & 7.689 & 19,9 \\
\hline Villa Nery & 438 & 1,1 \\
\hline Villa Pureza & 199 & 0,5 \\
\hline
\end{tabular}

Fonte: Recenseamento de 1907, São Carlos.

\section{Distribuição da população por sexo}

Conforme o esperado em se tratando de uma sociedade receptora de imigrantes, havia no município mais homens $(52,1 \%)$ do que mulheres $(47,9 \%)$. Contudo, tais proporções não se mantêm ao se analisarem separadamente os meios rural e urbano, pois, no primeiro, o percentual masculino $(52,9 \%)$ sobrepuja o feminino $(47,1 \%)$, enquanto na cidade há mais mulheres $(51 \%)$ do que homens (49\%). ${ }^{7}$ De fato, em relação ao seu próprio contingente, as mulheres encontram-se mais concentradas na área urbana $(23,6 \%$ do total de mulheres do município) do que os homens (20,9\% do total desses). As pirâmides etárias apresentadas nos Gráficos 3 e 4 permitem uma visão mais acurada do que se passa.

Neste perfil da pirâmide etária, é possível verificar que a dinâmica demográfica do município caracterizava-se não só por elevadas natalidade e mortalidade, mas também pela presença de um movimento imigratório acentuado. Os homens predominavam sobre as mulheres, principalmente nas faixas etárias produtivas e reprodutivas. A população apresentava-se jovem; as crianças de

\footnotetext{
${ }^{7}$ As razões de sexo nas áreas urbana e rural foram calculadas em 96,5 e 113, respectivamente.
} 


\section{GRÁFICO 3}

Pirâmide etária da população total, por sexo Município de São Carlos - 1907

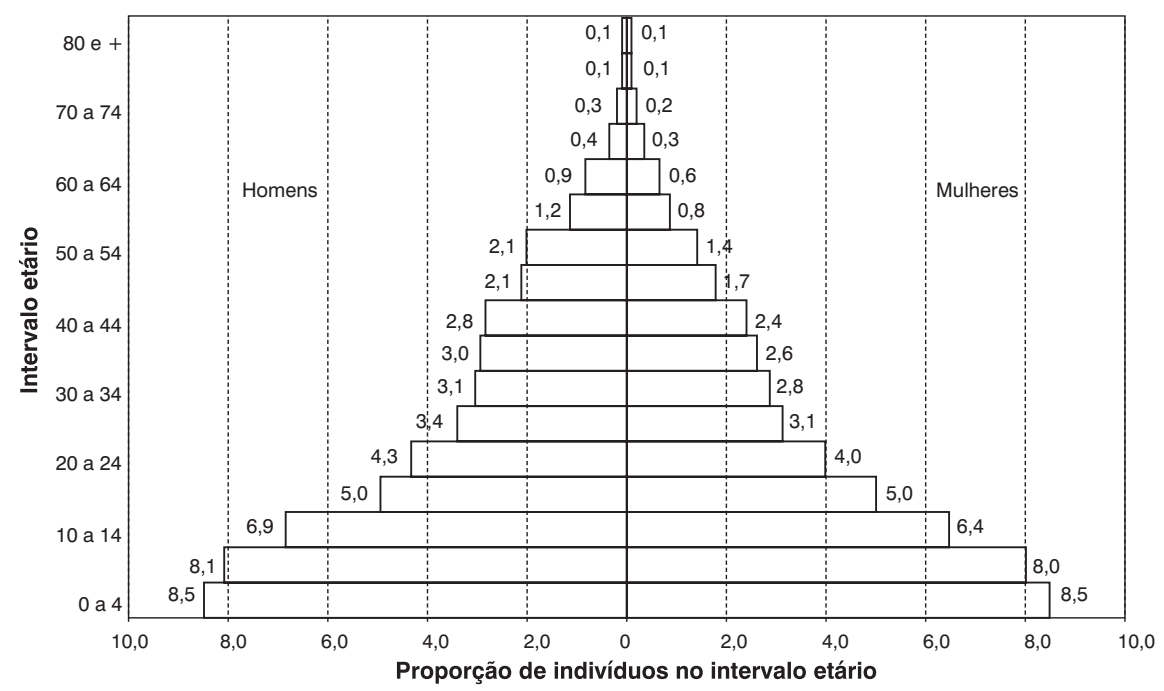

Fonte: Recenseamento de 1907, São Carlos.

GRÁFICO 4

Pirâmide etária da população urbana, por sexo Município de São Carlos - 1907

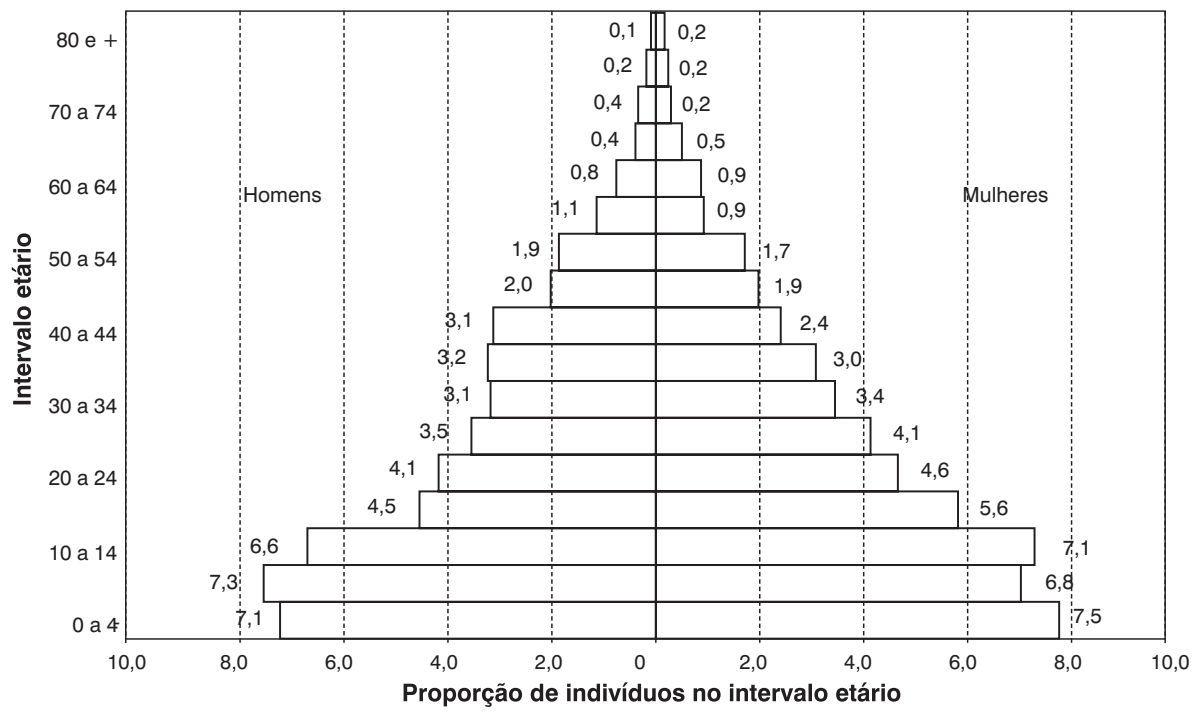

Fonte: Recenseamento de 1907, São Carlos.

até dez anos representavam mais de um terço da população, resultado de uma alta natalidade, para a qual contribuiu muito a população imigrante, que, chegada ao Brasil em idade reprodutiva ou ainda na infância, passava a gerar filhos, agora brasileiros.
Dado que na zona rural estava concentrada a maioria da população, a pirâmide demográfica é bastante semelhante à da população total, apresentada no Gráfico 3. Já o perfil da pirâmide da população urbana apresenta algumas diferenças da- 
quele relativo à população total, revelando uma população mais envelhecida do que na área rural: as crianças até dez anos representavam uma parcela menor no seu conjunto $(28,7 \%)$ do que a obtida para o rural $(34,2 \%)$. No que diz respeito à população considerada ativa, ou seja, aquela entre 15 e 64 anos de idade, a razão de sexo no meio urbano ficava bastante próxima à da população total e no rural alcançava a cifra de 121 homens para cada 100 mulheres. $O$ maior predomínio de mulheres no urbano era alcançado nas faixas etárias de 10 a 34 anos $(87,6)$, enquanto a maior concentração de homens dava-se nas idades entre 45 e 64 anos $(147,6)$.

\section{Composição étnico-racial da população e sua distribuição no território}

Como já salientado anteriormente, a composição étnico-racial sofreu grande alteração com a chegada dos imigrantes ao município de São Carlos. Observando-se a distribuição étnico-racial entre as áreas urbanas e rurais, constata-se em 1907, entre os brasileiros, a maior incidência relativa de pretos nas áreas urbanas $(26,5 \%$ do total de pretos no município), em relação a mulatos e brasileiros brancos $(22,4 \%$ e $25,5 \%$, dos respectivos totais).

No meio rural, o maior contingente de negros (801 indivíduos, $14,7 \%$ da população total da região) encontrava-se nas fazendas de Ibaté, embora relativamente o bairro de Fortaleza alcançava percentuais mais elevados $(26,1 \%)$ na população. A presença de brasileiros era mais marcante no meio urbano (quase $70 \%$ ) do que no rural (58\%). Entre os imigrantes, os italianos predominavam amplamente, atingindo quase $30 \%$ da popu- lação do município, sendo mais presentes no meio rural. Em algumas localidades, como Canchim e Colônia, eles representavam mais da metade da população local. É significativo que esses bairros rurais onde os italianos predominavam amplamente sejam os mesmos onde a população negra e mulata exiba as menores porcentagens de incidência (3,1\% e 7,1\%, respectivamente). Em contraposição, Fortaleza, caracterizada pelo alto percentual de negros $(26,1 \%)$, é também a localidade rural de menor presença italiana (13,3\%). Tal fenômeno pode ser indicativo tanto da existência de redes quanto da disputa entre negros e italianos no mercado de trabalho rural.

Afora brasileiros e italianos, os $10 \%$ restantes da população do município abrigavam espanhóis $(4,3 \%)$, portugueses $(4,2 \%)$, alemães, turcos e indivíduos de outras nacionalidades. Dos contingentes estrangeiros, os espanhóis, recém-chegados, eram os menos urbanizados (apenas 12,7\%), seguidos por italianos $(15,8 \%)$ e portugueses $(23,7 \%)$. Acompanhando o padrão étnico, dos 113 indivíduos registrados como turcos, todos, sem exceção, habitavam áreas urbanas ou os povoados de Ibaté, Santa Eudóxia e Água Vermelha.

Os portugueses atingiam taxas superiores a $10 \%$ da população nos bairros urbanos de Villa Izabel e Botafogo e no de Capão Preto, na zona rural. Os espanhóis, além do seu perfil eminentemente rural, já apontado, não se distribuíam uniformemente nas áreas rurais, mas, ao contrário, concentravam-se em alguns bairros, onde alcançavam proporções significativas, superiores a $10 \%$ : Pinhal, Visconde do Rio Claro, Capão Preto e Ararahy.

$\mathrm{Na}$ área urbana, já era possível se observar, desde então, a presença marcante

TABELA 4

Distribuição da população, por nacionalidade e cor, segundo domicílio Município de São Carlos - 1907

Em porcentagem

\begin{tabular}{|c|c|c|c|c|c|c|c|c|c|c|c|}
\hline \multirow{2}{*}{$\begin{array}{l}\text { Domi- } \\
\text { cílio }\end{array}$} & \multicolumn{4}{|c|}{ Brasileiros } & \multirow{2}{*}{ Italianos } & \multirow{2}{*}{ Portugueses } & \multirow{2}{*}{ Espanhóis } & \multirow{2}{*}{ Alemães } & \multirow{2}{*}{ Turcos } & \multirow{2}{*}{ Diversos } & \multirow{2}{*}{ Total } \\
\hline & Total & Brancos & Pretos & Mulatos & & & & & & & \\
\hline Rural & 74,5 & 74,5 & 73,5 & 77,6 & 84,2 & 76,3 & 87,3 & 73,2 & 28,3 & 70,1 & 77,8 \\
\hline Urbano & 25,5 & 25,5 & 26,5 & 22,4 & 15,8 & 23,7 & 12,7 & 26,8 & 71,7 & 29,9 & 22,2 \\
\hline
\end{tabular}

Fonte: Recenseamento de 1907, São Carlos. 
de negros (pretos e mulatos) nas vilas mais afastadas (Pureza, Isabel e Nery), com participações $(44,7 \%, 33,1 \%$ e $24,4 \%$, respectivamente) bem acima da média de outros locais, tanto do núcleo urbano mais central, onde a população negra não atingia $10 \%$ dos habitantes, quanto das zonas rurais (em que a participação do contingente negro era ainda menor). Assim, a maior incidência de negros nas vilas citadas explica-se porque foi precisamente nesses locais, relativamente mais distantes do centro urbano, que os negros se instalaram ao deixarem as fazendas de café, após a abolição. Conquanto não se possa falar em segregação espacial, pois somadas, as populações negras dessas três vilas não atingiam nem um quarto do total da população negra da cidade, já é nítido um processo de periferização dessa população. De fato, conforme ilustra a Tabela 5, ao se considerarem os quatro bairros (Vilas Pureza, Isabel, Nery e Botafogo) mais os subúrbios como periferia do núcleo urbano central, observa-se que a chance de um negro (preto ou mulato) habitar a periferia era quase o dobro daquela de um brasileiro branco ou de um estrangeiro.

\section{Estado civil}

No tocante ao estado civil, foram considerados apenas os homens com no mínimo 16 anos e as mulheres com no mínimo 14 anos de idade, para que a população de solteiros não fosse superestimada pela influência das crianças. ${ }^{8}$

Em 1907, havia no município 10.661 homens e 10.139 mulheres com no mínimo
16 e 14 anos, respectivamente, perfazendo 20.800 indivíduos. Considerando-se esse universo, predominavam os casados $(62,7 \%)$ sobre os solteiros $(30,7 \%)$ e viúvos $(6,6 \%)$. No meio urbano, os solteiros $(34,4 \%)$ e, sobretudo, os viúvos $(9,9 \%)$ aumentavam sua representatividade, o que, nesse último caso, é indicativo do efeito de atração que a cidade exercia sobre o grupo ou, ao contrário, da menor disposição do meio rural em manter indivíduos mais idosos e provavelmente menos produtivos. Além disso, dada a importância do trabalho familiar, tanto na grande fazenda de café quanto na pequena propriedade rural, é provável que indivíduos vivendo sozinhos fossem mais atraídos pela cidade. De qualquer modo, do total de viúvos habitando o município, mais de $35 \%$ residiam em áreas urbanas, em contraste com percentuais mais discretos de casados (em torno de $21 \%$ ) e de solteiros (cerca de 27\%).

Ainda é preciso chamar a atenção aqui para a possibilidade de ocorrerem uniões consensuais, prática comum tanto entre segmentos da população nativa quanto entre imigrantes que tencionam permanecer temporariamente no país que os acolheu. Como não dispomos de nenhuma instrução sobre o procedimento de coleta de dados do censo, não se sabe como foram tratados tais casos. De qualquer modo, em relação a 1886, diminuiu a proporção de solteiros de uma maneira geral como resultado do aumento das uniões formais, provavelmente porque os imigrantes, além de mais numerosos em 1907, já estavam habituados ao casamento formal. Assim, em 1886, a

TABELA 5

Distribuição da população urbana, por nacionalidade e cor, segundo domicílio Município de São Carlos - 1907

\begin{tabular}{|c|c|c|c|c|c|c|}
\hline \multirow{2}{*}{ Domicílio } & \multicolumn{2}{|c|}{ Brasileiros brancos } & \multicolumn{2}{|c|}{ Brasileiros negros } & \multicolumn{2}{|c|}{ Estrangeiros } \\
\hline & N. abs. & $\%$ & N. abs. & $\%$ & N. abs. & $\%$ \\
\hline Centro & 4.397 & 85,5 & 941 & 71,1 & 2.377 & 83,2 \\
\hline Periferia & 748 & 14,5 & 383 & 28,9 & 480 & 16,8 \\
\hline
\end{tabular}

Fonte: Recenseamento de 1907, São Carlos.

\footnotetext{
8 O Decreto 181, de 24 de janeiro de 1890, na época vigente, proibia o casamento abaixo de tais idades, respectivamente para homens e mulheres, sendo que, entre estas idades e a de 21 anos, o casamento, para ser realizado, necessitava do consentimento dos pais.
} 
proporção de solteiros entre indivíduos de 16 anos e mais era de 39,3\%; em 1907, a mesma proporção para pessoas de 15 anos e mais era consideravelmente menor: $22,9 \%$.

É interessante ainda mencionar outro aspecto sobre as proporções entre homens e mulheres. Do total de homens, 3.641 eram solteiros, 6.590 casados e 430 viúvos. Entre as mulheres, 2.743 eram solteiras, 6.446 casadas e 950 viúvas. Havia, portanto, certa desproporção, de um lado, entre homens e mulheres solteiros (133 para 100) ${ }^{9} \mathrm{e}$, de outro, entre homens e mulheres viúvos, estas muito mais numerosas (100 para 221), enquanto, entre casados, as frações eram semelhantes (102 para 100). Tais desequilíbrios são indicativos de uma sociedade receptora de imigrantes trabalhadores, na qual os homens solteiros tendem a prevalecer sobre as mulheres solteiras em áreas rurais (tornando-as mais disputadas no mercado matrimonial) e a longevidade feminina é maior do que a masculina. Também não se pode esquecer que os viúvos recasam-se muito mais do que as viúvas, daí haver menos viúvos do que viúvas. No meio urbano, por exemplo, há quase quatro vezes mais viúvas do que viúvos.

Já uma análise dos grupos étnicoraciais segundo o estado civil evidencia di- ferenças muito significativas entre estrangeiros e brasileiros. Conforme mostra a Tabela 6 , enquanto apenas a metade dos brasileiros é casada, no caso dos estrangeiros esta cifra se eleva para $70 \%$. Tal fenômeno possivelmente está associado à característica familiar da imigração e ao costume mais difundido entre estrangeiros de formalizar as uniões, já aludido. Por outro lado, também chama atenção a circunstância de haver percentuais maiores de casados entre brasileiros negros (tanto pretos quanto mulatos) do que entre brancos, provavelmente porque os primeiros tivessem mais necessidade de se valer do casamento como uma estratégia de reconhecimento social. ${ }^{10}$

\section{Instrução}

No tocante à instrução, o censo distingue entre os que sabiam e os que não sabiam ler. No total do município, considerando-se a população de no mínimo 12 anos de idade (23.773 indivíduos), 8.400 sabiam ler (apenas 35\% da população) e 15.371 não. Entre esses últimos, mais de $85 \%$ habitavam as áreas rurais. Havia, portanto, diferenças bastante acentuadas entre os meios urbano e rural: nesse último, apenas $28 \%$ da população foi registrada como tendo

TABELA 6

Distribuição da população (1), por nacionalidade e cor, segundo o estado civil Município de São Carlos - 1907

\begin{tabular}{|c|c|c|c|c|c|c|c|c|c|c|c|c|}
\hline \multirow{2}{*}{$\begin{array}{l}\text { Estado } \\
\text { civil }\end{array}$} & \multicolumn{4}{|c|}{ Brasileiros } & \multicolumn{7}{|c|}{ Estrangeiros } & \multirow[b]{2}{*}{ Total } \\
\hline & Total & Brancos & Pretos & Mulatos & Total & Italianos & $\begin{array}{c}\text { Portu- } \\
\text { gueses }\end{array}$ & Espanhóis & Alemães & Turcos & Diversos & \\
\hline Casados & 3.969 & 2.364 & 1.285 & 320 & 9.067 & 6.903 & 967 & 831 & 138 & 67 & 161 & 13.036 \\
\hline$\%$ & 50,3 & 46,8 & 55,5 & 59,5 & 70,3 & 70,7 & 68,0 & 71,2 & 71,1 & 65,1 & 64,4 & 62,7 \\
\hline Solteiros & 3.281 & 2.299 & 798 & 184 & 3.103 & 2.284 & 389 & 283 & 38 & 33 & 76 & 6.384 \\
\hline$\%$ & 41,5 & 45,6 & 34,4 & 34,2 & 24,1 & 23,4 & 27,4 & 24,3 & 19,6 & 32,0 & 30,4 & 30,7 \\
\hline Viúvos & 650 & 382 & 234 & 34 & 730 & 578 & 65 & 53 & 18 & 3 & 13 & 1.380 \\
\hline$\%$ & 8,2 & 7,6 & 10,1 & 6,3 & 5,6 & 5,9 & 4,6 & 4,5 & 9,3 & 2,9 & 5,2 & 6,6 \\
\hline Total & 7.900 & 5.045 & 2.317 & 538 & 12.900 & 9.765 & 1.421 & 1.167 & 194 & 103 & 250 & 20.800 \\
\hline$\%$ & 100,0 & 100,0 & 100,0 & 100,0 & 100,0 & 100,0 & 100,0 & 100,0 & 100,0 & 100,0 & 100,0 & 100,0 \\
\hline
\end{tabular}

Fonte: Recenseamento de 1907, São Carlos.

(1) Refere-se aos homens de 16 anos ou mais e às mulheres de 14 anos ou mais.

\footnotetext{
90 desequilíbrio ocorre nas áreas rurais (149 para 100).

10 Tais dados condizem com o boom de casamentos de ex-escravos nos anos subsequentes à abolição.
} 
capacidade de leitura, enquanto no meio urbano tal índice se elevava a quase $60 \%$.

Além das possibilidades abertas na cidade quanto à frequência à escola, algumas atividades urbanas exigiam que o indivíduo fosse alfabetizado. Entre homens e mulheres também havia diferenças significativas em prejuízo destas: $42,8 \%$ dos homens e $26,8 \%$ das mulheres com 12 anos ou mais no município sabiam ler.

Cruzando-se a capacidade de leitura com a variável cor e nacionalidade, observase que apenas um quinto dos brasileiros sabia ler, sendo que, entre esses, o contingente mais prejudicado era o de pretos e mulatos, em que $10 \%$ o faziam. Entre os estrangeiros, os espanhóis exibiam as taxas menores ${ }^{11}$ (um quarto do grupo), italianos e portugueses registravam cerca de $30 \%$, seguidos por turcos, diversos e alemães, esses últimos contando com $60 \%$ do grupo com capacidade de leitura.

\section{Profissões}

O extenso rol das profissões apresentadas pelo censo constitui um bom indicativo do grau elevado de desenvolvimento da divisão social do trabalho da época. O complexo cafeeiro exigia uma pauta de atividades relativamente diversificada, abrindo um leque amplo de oportunidades de trabalho não propriamente agrícola, tanto na zona rural como na urbana. Aqui também cabe uma ressalva a respeito do critério adotado para a construção da tabela, que é diferente da apresentada pelo censo. Usualmente, depara-se na leitura do censo com crianças registradas com a profissão do pai (por exemplo: Fulano de tal, dois anos, negociante). Para corrigir tal distorção nas tabelas de profissões, computam-se apenas os indivíduos com, no mínimo, 12 anos de idade, embora fosse comum, no meio rural, crianças a partir de oito anos ajudarem seus pais com as lides da lavoura, o mesmo podendo ocorrer em algumas atividades no meio urbano. Assim, o universo considerado para a análise que se segue das profissões compõe-se não da população total, mas dos 23.773 indivíduos com no mínimo 12 anos de idade.

Como os subúrbios da cidade e ainda os núcleos das vilas de Ibaté e Santa Eudóxia acham-se incluídos na zona rural, é claro que se encontram aí profissões de feitio mais urbano. Observe-se, porém, que, mesmo excluindo-se da zona rural tais contingentes, a gama de profissões existentes nas regiões estritamente rurais ainda é bastante significativa, o que pode indicar a relativa autossuficiência das fazendas da época. De fato, nas grandes propriedades, é comum existirem profissionais como escrivão, guarda-livros, ferreiro, intérprete, marceneiro, professor, pedreiro, seleiro e até matador de formigas. ${ }^{12}$

É claro que as classificações adotadas pelo censo são muitas vezes imprecisas, como ocorre, por exemplo, com a categoria "lavrador", que pode denotar, ao mesmo tempo, o proprietário de terras ou simplesmente o trabalhador agrícola, remunerado como assalariado, parceiro ou colono. De qualquer forma, observa-se que, entre os lavradores, mais de $70 \%$ são proprietários, enquanto para colonos esse percentual não atinge $1 \%$ ( $7 \%$ para camaradas e $20 \%$ para administradores), o que indica uma clara correlação entre lavradores e proprietários. Tudo leva a crer que a profissão de lavrador, por ser mais abrangente, compreenda todos os indivíduos responsáveis por decisões envolvendo o cultivo de terras, "quer seja por sua conta e por suas mãos, quer seja por conta de outrem a quem pague, seja, enfim, como proprietário ou rendeiro" (BARBOSA, 1943, p. 51).

Outro exemplo são as ambiguidades produzidas pelas categorias negociante e comerciante; feitor (de turma e de fazenda), fiscal e supervisor; empregado, criado e doméstica, etc. Trabalhador também aparece como uma categoria pouco específica,

\footnotetext{
${ }^{11}$ Nesse ponto, São Carlos se alinha com os dados obtidos por Klein (1994) para o total do Estado, que também apontam os espanhóis como os menos alfabetizados.

12 Bassanezi (1974) arrolou cerca de meia centena de ocupações diferentes exercidas pelos trabalhadores da mais importante fazenda cafeeira do município de Rio Claro: a Fazenda de Santa Gertrudes.
} 
distinta de operário. De qualquer modo, não há informações se as categorias registradas refletem aquilo que o indivíduo declarou ou a percepção do funcionário que coletou os dados, ou ainda, o que é mais provável, uma mistura dos dois.

A Tabela 7 relaciona perfis étnico-raciais da população com as ocupações mais frequentes no meio rural. Dos 18.123 indivíduos de 12 anos ou mais, dois terços eram colonos. Destes, quase $60 \%$ eram italianos e os brasileiros somavam $25 \%$, figurando a seguir espanhóis (8\%) e portugueses (6\%). Entre os 3.016 brasileiros colonos, 1.848 eram brancos, 990 eram pretos e 178 mulatos. Chama atenção aqui a presença significativa de famílias de colonos negros (pretos e mulatos provavelmente remanescentes da época da escravidão), mais numerosos do que colonos portugueses ou espanhóis, ao arrepio do que normalmente é referido na literatura, que normalmente atribui a tal grupo ocupações mais periféricas no latifúndio cafeeiro (como a de camaradas), ou mesmo o abandono das fazendas por ocasião da abolição da escravidão. Como observou Monsma (2006), os negros nem foram excluídos e nem se autoexcluíram do regime de colonato (ver também PALMA, 2007). Mais de um terço dos indivíduos maiores de 12 anos pretos ou mulatos foram registrados como colonos.
Entre lavradores, havia uma clara predominância de brasileiros brancos (quase $60 \%$ ), além dos italianos que já respondiam por um quarto desta ocupação, enquanto os brasileiros negros não somavam $10 \%$. Estes eram mais abundantes entre camaradas, empregados e cozinheiros. Quase três quartos dos administradores eram brasileiros brancos (talvez porque, nessa época, os fazendeiros ainda temessem contratar estrangeiros para essa função, ou porque preferissem indivíduos com o domínio da língua), que também se destacavam entre os ferroviários (50\%) e empreiteiros (39\%). Os italianos, além de colonos, representavam $55 \%$ dos negociantes no meio rural e disputavam com brasileiros negros a profissão de carroceiro e carreiro, ocupações manuais com pouca qualificação.

No meio propriamente urbano, onde se distinguem as profissões apresentadas pela Tabela 8, há continuidades e algumas mudanças em relação às ocupações na área rural. Os italianos permanecem se destacando entre os negociantes (mais da metade) e os brasileiros brancos entre os lavradores (58\%). Em contrapartida, estes, no meio urbano, passam a ser mais frequentes do que os negros na profissão de empregados (46\%), além de constituírem $58 \%$ das costureiras. Os negros estão mais representados em profissões subalternas - cozinheiro $(68 \%)$,

TABELA 7

Ocupados em profissões rurais com mais de $\mathbf{5 0}$ indivíduos, por nacionalidade e cor Município de São Carlos - 1907

\begin{tabular}{|c|c|c|c|c|c|c|c|c|c|c|c|}
\hline \multirow{2}{*}{ Profissão } & \multicolumn{4}{|c|}{ Brasileiros } & \multirow{2}{*}{ - Italianos } & \multirow{2}{*}{$\begin{array}{l}\text { Portugue- } \\
\text { ses }\end{array}$} & \multirow{2}{*}{ Espanhóis } & \multirow{2}{*}{ Alemães } & \multirow{2}{*}{ Turcos } & \multirow{2}{*}{ Diversos } & \multirow{2}{*}{ Total } \\
\hline & Total & Brancos & Pretos & Mulatos & & & & & & & \\
\hline Colono & 3.016 & 1.848 & 990 & 178 & 7.132 & 706 & 971 & 89 & 0 & 152 & 12.066 \\
\hline Lavrador & 1.328 & 1.144 & 139 & 45 & 504 & 88 & 15 & 16 & 1 & 3 & 1.955 \\
\hline Camarada & 819 & 326 & 383 & 110 & 330 & 99 & 40 & 10 & 1 & 11 & 1.310 \\
\hline Empregado & 219 & 99 & 92 & 28 & 59 & 19 & 2 & 1 & 3 & 0 & 303 \\
\hline Administrador & 165 & 155 & 8 & 2 & 34 & 6 & 6 & 0 & 0 & 1 & 212 \\
\hline Empreiteiro & 89 & 64 & 19 & 6 & 43 & 29 & 0 & 2 & 1 & 0 & 164 \\
\hline Negociante & 32 & 32 & 0 & 0 & 80 & 10 & 9 & 0 & 14 & 1 & 146 \\
\hline Carroceiro (1) & 66 & 28 & 37 & 1 & 35 & 3 & 5 & 0 & 0 & 0 & 109 \\
\hline Ferroviário (2) & 32 & 30 & 0 & 2 & 6 & 16 & 7 & 1 & 0 & 2 & 64 \\
\hline Cozinheiro & 45 & 8 & 26 & 11 & 10 & 1 & 0 & 0 & 0 & 1 & 57 \\
\hline
\end{tabular}

Fonte: Recenseamento 1907, São Carlos.

(1) Inclui carreiros.

(2) Inclui empregados da Cia. Paulista, empregados de estação, empregados da estrada de ferro, chefes de estação. 
lavadeira (46\%) e criado (41\%) - e ainda disputam com os italianos a profissão de camaradas (residentes em área urbana).

Os italianos constituíam três quartos dos carroceiros e sapateiros, sendo também bastante representativos entre os alfaiates (65\%) e trabalhadores (48\%). Os portugueses, por sua vez, ainda que numericamente pouco expressivos, encontravam-se sobrerepresentados entre os ferroviários, com mais de $30 \%$ dos postos de trabalho (já representavam um quarto dessa ocupação nas áreas rurais), logo abaixo de brasileiros brancos (40\%). Dos 61 estudantes compilados pelo censo que habitavam a área urbana, nada menos que 58 eram brasi- leiros brancos. Chama também atenção a concentração ocupacional dos turcos: 46 negociantes entre 47 indivíduos.

\section{A situação de proprietário segundo condição étnico-racial}

A circunstância de ser ou não proprietário, atribuída a cada indivíduo, pode fornecer uma aproximação do desempenho e da inserção na estrutura social de cada grupo étnico-racial no período estudado. Para tanto, consideraram-se os indivíduos de no mínimo 21 anos de idade, tanto em áreas urbanas quanto rurais. A Tabela 9 expõe tais resultados, expressos em percentuais.

TABELA 8

Ocupados em profissões urbanas com mais de 50 indivíduos, por nacionalidade e cor

Município de São Carlos - 1907

\begin{tabular}{|c|c|c|c|c|c|c|c|c|c|c|c|}
\hline \multirow[b]{2}{*}{ Profissão } & \multicolumn{4}{|c|}{ Brasileiros } & \multirow[b]{2}{*}{ Italianos } & \multirow{2}{*}{$\begin{array}{l}\text { Portu- } \\
\text { gueses }\end{array}$} & \multirow[b]{2}{*}{ Espanhóis } & \multirow[b]{2}{*}{ Alemães } & \multirow[b]{2}{*}{ Turcos } & \multirow[b]{2}{*}{ Diversos } & \multirow[b]{2}{*}{ Tota } \\
\hline & Total & Brancos & Pretos & Mulatos & & & & & & & \\
\hline Negociante & 87 & 82 & 2 & 3 & 190 & 26 & 15 & 4 & 46 & 2 & 370 \\
\hline Camarada & 169 & 57 & 101 & 11 & 120 & 51 & 18 & 1 & 0 & 7 & 366 \\
\hline Lavrador & 237 & 194 & 30 & 13 & 38 & 35 & 21 & 2 & 0 & 2 & 335 \\
\hline Empregado & 221 & 161 & 52 & 8 & 76 & 32 & 10 & 0 & 1 & 7 & 347 \\
\hline Costureira & 125 & 110 & 11 & 4 & 45 & 10 & 3 & 4 & 0 & 2 & 189 \\
\hline Cozinheiro & 145 & 31 & 105 & 9 & 18 & 0 & 0 & 2 & 0 & 2 & 167 \\
\hline Criado & 93 & 40 & 50 & 3 & 25 & 4 & 3 & 1 & 0 & 4 & 130 \\
\hline Lavadeira & 97 & 39 & 51 & 7 & 23 & 2 & 3 & 1 & 0 & 0 & 126 \\
\hline Ferroviário (1) & 65 & 52 & 11 & 2 & 11 & 37 & 11 & 0 & 0 & 0 & 124 \\
\hline Carroceiro (2) & 16 & 7 & 9 & 0 & 68 & 6 & 0 & 0 & 0 & 0 & 90 \\
\hline Sapateiro & 18 & 18 & 0 & 0 & 57 & 0 & 0 & 0 & 0 & 3 & 78 \\
\hline Estudante & 60 & 58 & 0 & 2 & 1 & 0 & 0 & 0 & 0 & 0 & 61 \\
\hline Alfaiate & 19 & 18 & 0 & 1 & 38 & 1 & 0 & 0 & 0 & 0 & 58 \\
\hline Trabalhador & 27 & 19 & 8 & 0 & 28 & 3 & 0 & 0 & 0 & 0 & 58 \\
\hline
\end{tabular}

Fonte: Recenseamento de 1907, São Carlos.

(1) Inclui empregados da Cia. Paulista, empregados de estação, empregados da estrada de ferro, chefes de estação.

(2) Inclui carreiros.

TABELA 9

Proprietários (21 anos ou mais) nos meios rural e urbano, por nacionalidade e cor Município de São Carlos - 1907

Em porcentagem

\begin{tabular}{|c|c|c|c|c|c|c|c|c|c|c|c|}
\hline \multirow{2}{*}{ Área } & \multicolumn{4}{|c|}{ Brasileiros } & \multirow{2}{*}{ Italianos } & \multirow{2}{*}{ Portugueses } & \multirow{2}{*}{ Espanhóis } & \multirow{2}{*}{ Alemães } & \multirow{2}{*}{ Turcos } & \multirow{2}{*}{ Diversos } & \multirow[b]{2}{*}{ Total } \\
\hline & Total & Brancos & Pretos & Mulatos & & & & & & & \\
\hline Rural & 21,2 & 33,0 & 4,7 & 8,7 & 7,5 & 13,8 & 3,8 & 14,5 & 47,8 & 7,4 & 11,9 \\
\hline Urbana & 40,1 & 43,0 & 33,2 & 39,7 & 38,5 & 45,2 & 33,1 & 39,2 & 36,2 & 53,0 & 39,8 \\
\hline Total & 27,4 & 36,6 & 12,7 & 15,7 & 13,1 & 22,1 & 8,7 & 21,4 & 39,5 & 22,7 & 18,7 \\
\hline
\end{tabular}

Fonte: Recenseamento de 1907, São Carlos. 
Em primeiro lugar, os dados demonstram que era mais fácil (porque mais barato) ser proprietário no meio urbano do que no rural. De fato, no primeiro, quase $40 \%$ dos indivíduos maiores de 21 anos eram proprietários, enquanto no segundo essa proporção não atinge $12 \%$. Chama a atenção, em ambas as situações, os baixos índices dos espanhóis proprietários, inferiores inclusive aos de brasileiros negros. Isso se deve, em parte, à sua condição de recém-chegados. No meio urbano, o grupo diversos é o que mais detém, relativamente a seu tamanho, propriedades, seguido por portugueses e brasileiros brancos.

No meio rural, ser proprietário inclui tanto aqueles que detinham propriedades agrícolas, quanto os que possuíam apenas uma casa, ou um comércio, desde que localizados na zona rural. Nesse caso, despontam os turcos (sírios e libaneses), acompanhados dos brasileiros brancos (muito distintos de brasileiros negros). Entre os estrangeiros, após os turcos, alemães e portugueses se destacam, relativamente a seus contingentes.

Em termos absolutos, consoante a expressão numérica do grupo, os italianos predominavam, entre os estrangeiros, como proprietários no meio rural. Trata-se, obviamente, de propriedades relativamente pequenas. A Estatística Agrícola realizada poucos anos antes, referente ao ano agrícola 1904-1905, indicou que havia no município 313 estabelecimentos rurais, $80,5 \%$ dos quais eram de propriedade de brasileiros. O maior contingente de proprietários estrangeiros era composto justamente pelos italianos (12,8\%), sendo que metade deles possuía até dez alqueires e $37,5 \%$ eram donos de terras cujas áreas ficavam entre 10 e 50 alqueires (BASSANEZI; FRANCISCO, 2003; TRUZZI, 2004).

\section{Elites e associações de cunho étnico-racial}

Em uma sociedade receptora de imigrantes, emersa há menos de duas décadas do regime escravista, é relevante observar em que medida os diferentes grupos étnicoraciais lograram se organizar, constituir interlocutores e mesmo adentrar ao círculo restrito das elites rurais locais. Um dos indicadores de permeabilidade, já comentado, refere-se ao acesso à propriedade - sobretudo rural - desses diferentes grupos. Outro possível indicador, aproximativo, diz respeito à entrada de indivíduos em profissões ou atividades de algum prestígio para a época.

É notável o quase monopólio de brasileiros brancos entre profissionais liberais (médicos, advogados, farmacêuticos e professores) e em cargos de direção na ferrovia (considerada um ótimo local de trabalho). Além disso, eles dominavam amplamente entre funcionários públicos, comerciantes (provavelmente de café) e administradores de fazendas (Tabela 10).

Os italianos, numerosos entre os imigrantes, já se insinuavam em algumas dessas ocupações, mas predominavam mesmo entre os negociantes, industriais e diretores de colônia. Notáveis são ainda as presenças de alemães entre engenheiros, portugueses entre feitores e de turcos entre negociantes. Ressalte-se ainda a participação muito pequena de negros nesse quadro: nenhum entre as categorias mais prestigiosas e apenas cinco negociantes, cinco administradores, dois feitores e um industrial, perfazendo apenas $13 \mathrm{em}$ um conjunto de 634 indivíduos. ${ }^{13}$

Relativamente à capacidade mobilizadora e organizativa dos diferentes grupos, no caso de São Carlos, é incontestável a influência da maçonaria, desde 1874, quando parece ter sido fundada a primeira loja, que reunia muitos fazendeiros e o próprio pároco local. Nos anos 80 do século XIX, dois clubes de recreação e instrutivos disputavam a adesão dos cidadãos brasileiros e brancos mais abastados da cidade.

Entre imigrantes, os espanhóis foram os primeiros a propor, já em 1892, uma Sociedade Espanhola de Socorros Mútuos (O Popular, 17 de março de 1892). Ao que parece, o intento foi realizado em 1896, com a fundação da Sociedade Espanhola

\footnotetext{
${ }^{13}$ Registre-se aqui, como notória exceção, o fazendeiro e ativo negociante mulato Argêo Vinhas, casado com uma italiana, proprietário rural, ex-delegado de polícia, sócio de uma fábrica de tecidos implantada em 1911 e responsável pela instalação das linhas de bonde em São Carlos no ano seguinte.
} 
TABELA 10

Profissionais liberais, industriais, comerciantes, funcionários públicos e ocupantes de cargos de direção na ferrovia e nas fazendas (21 anos ou mais), por nacionalidade e cor

Município de São Carlos - 1907

\begin{tabular}{|c|c|c|c|c|c|c|c|c|c|c|c|}
\hline \multirow{2}{*}{ Profissão } & \multicolumn{4}{|c|}{ Brasileiros } & \multirow{2}{*}{ - Italianos } & \multirow{2}{*}{ Portugueses } & \multirow{2}{*}{ Espanhóis } & \multirow{2}{*}{ Alemães } & \multirow{2}{*}{ Turcos } & \multirow{2}{*}{ Diversos } & \multirow{2}{*}{ Tota } \\
\hline & Total & Brancos & Pretos & Mulatos & & & & & & & \\
\hline Advogados/juiz & 8 & 8 & - & - & - & - & - & - & - & - & 8 \\
\hline Médicos & 9 & 9 & - & - & 1 & - & - & - & - & - & 10 \\
\hline Farmacêuticos & 19 & 19 & - & - & 2 & - & - & - & - & - & 21 \\
\hline Engenheiros & 1 & 1 & - & - & - & - & - & 3 & - & - & 4 \\
\hline Professores & 17 & 17 & - & - & 6 & 2 & - & - & - & 2 & 27 \\
\hline Func. público & 8 & 8 & - & - & 2 & 3 & - & - & - & - & 13 \\
\hline Chefes estação & 13 & 13 & - & - & 1 & 1 & - & - & - & - & 15 \\
\hline Banqueiros & 2 & 2 & - & - & 1 & - & - & - & - & - & 3 \\
\hline Industriais & 2 & 1 & 1 & - & 11 & 2 & 2 & 1 & - & 1 & 19 \\
\hline Comerciantes & 34 & 34 & - & - & 19 & 7 & 1 & - & 1 & - & 62 \\
\hline Negociantes & 41 & 36 & 2 & 3 & 175 & 28 & 17 & 3 & 34 & 2 & 300 \\
\hline Administradores & 95 & 90 & 3 & 2 & 16 & 5 & 4 & - & - & - & 120 \\
\hline Diretores & 1 & 1 & - & - & 7 & 1 & 1 & - & - & 1 & 11 \\
\hline Feitores & 7 & 5 & 1 & 1 & 3 & 11 & - & - & - & - & 21 \\
\hline Total & 257 & 244 & 7 & 6 & 244 & 60 & 25 & 7 & 35 & 6 & 634 \\
\hline
\end{tabular}

Fonte: Recenseamento de 1907, São Carlos.

Beneficente e Instrutiva de São Carlos, que funcionou em prédio próprio desde sua fundação. Presidida por um fotógrafo, sua primeira diretoria reunia negociantes e um industrial.

Os italianos, por sua vez, lograram fundar, já em 1894, uma loja maçônica própria, a "Cristoforo Colombo", de perfil anticlerical, cujas sessões transcorriam em italiano. Ao final do século XIX, sua diretoria era composta em maioria por negociantes, ao lado de um médico (o Dr. Vicenzo Pellicano, formado pela Universidade de Nápoles) e de um alfaiate. $O$ fato de essa loja maçônica ter se desarticulado no final do século XIX e de vários de seus membros terem colaborado na fundação de outra loja, de perfil mais abrangente, cuja diretoria reunia indivíduos de distintas origens e profissões, já denota a precoce integração da elite urbana italiana à determinada parcela das elites locais. Entre os membros dessa nova loja, da qual muitos italianos participavam ativamente, incluíamse também fazendeiros e políticos locais.
Outras duas associações italianas surgiram nos albores do século XX: a Meridionali Uniti Vittorio Emmanuele III, em 1900, que reunia italianos do sul; e a Dante Alighieri, em 1902, mais conhecida porque, por muitos anos, manteve uma escola para filhos da colônia italiana. Por iniciativa dessa última, fundou-se, ainda em 1903, o Patronato degli Emigranti, presidido pelo Dr. Pellicano, com o intuito de amparar os colonos em suas relações de trabalho.

Os portugueses tentaram se organizar, mas tudo indica que não lograram fundar uma associação própria. Como já mencionado, entre eles havia vários empregados na ferrovia e estes sim não tardaram a fundar, em 1905, uma associação denominada Protectora das Famílias dos Empregados da Companhia Paulista.

Já a população negra demorou bem mais para se organizar. A Sociedade Recreativa Flor de Maio, até hoje em funcionamento, foi fundada apenas em 1928, por ferroviários, detentores de um emprego 
digno, mas que não podiam entrar em outras associações graças ao preconceito de cor. Antes disso, há notícias da fundação, em 1908, portanto duas décadas após a abolição, da Sociedade Beneficente Luís Gama, presidida em 1912 por João Anacleto de Paula e Silva, residente nos arrabaldes da cidade. ${ }^{14}$ Infelizmente, não há mais informações sobre essa instituição, embora haja indícios de que estivesse ativa em 1915, quando da publicação de um almanaque local. ${ }^{15}$

De qualquer modo, é muito contrastante a situação da colônia italiana com a dos negros. Enquanto a primeira estava organizada em várias associações, mantinha uma escola para seus filhos, dominava o comércio local e dispunha de profissionais em ocupações de algum prestígio, os negros, discriminados pelos brancos de modo geral, só conseguiram se organizar mais tardiamente, e contavam com muito poucos interlocutores junto às elites locais.

\section{Considerações finais}

Fundado em meados do século XIX à beira do segundo degrau do Planalto Ocidental, além de Rio Claro e aquém de Araraquara, São Carlos logo se conformou como um município típico do segundo ciclo da economia cafeeira paulista. Suas lavouras, inicialmente tocadas a braço escravo, passaram a acolher, a partir do último quartel do século XIX, contingentes numerosos de imigrantes, sobretudo italianos, que provocaram um impacto decisivo em sua população.

Tais transformações, ocorridas em um período no qual os censos nacionais foram deficitários, podem agora ser captadas plenamente graças à existência de um censo municipal, que permite apresentar em detaIhes o perfil da população de um município dos mais significativos da economia cafeeira paulista. Assim, destacam-se a predominância dos domicílios rurais na razão de 3 para 1, a maciça presença de italianos, que compunham cerca de $30 \%$ da população total (sem contar seus filhos nascidos no Brasil), a maior incidência de homens em zonas rurais, a maior importância da família e da instrução entre os imigrantes, bem como as diferenças significativas entre eles e entre os meios rural e urbano.

Entre tais características, procurou-se ainda deslindar aqui as especificidades dos diferentes grupos étnico-raciais e, sobretudo, os indícios de seu posicionamento na estrutura social vigente, apreendidos, principalmente, pela inserção ocupacional, por padrões domiciliares na cidade, pelo acesso à propriedade, seja rural ou urbana, e pela capacidade associativa. Neste quadro, é inevitável constatar que os negros, menos de duas décadas após a abolição, acumulavam handicaps significativos: profissionalmente, embora não excluídos (como supõe de modo geral a literatura) do regime de colonato, encontravam-se sobre-representados em profissões subalternas e alijados tanto de ocupações mais prestigiosas quanto dos cargos de comando; em relação a outros grupos, apresentavam ainda taxas elevadas de analfabetismo, dificuldade em se organizar, maior chance de habitar a periferia urbana, menos propriedades e menor interlocução junto às elites locais.

Assim, os resultados apontam no sentido de corroborar a noção de que os imigrantes de fato adentraram a estrutura social paulista em um patamar diferenciado em relação aos negros saídos há pouco da escravidão. Embora os imigrantes fossem recém-chegados, rapidamente estabeleceram-se identidades contrastivas no tecido social, entre brancos e não-brancos: inclusiva para os imigrantes e discriminatória para pretos e mulatos. O resultado é um panorama demográfico rico, diversificado e racialmente excludente, de um município representativo de uma fase tão decisiva da história da economia cafeeira paulista.

\footnotetext{
14 Em 1907, João Anacleto tinha 35 anos, era casado, sabia ler e tinha um filho de 14 anos que nessa época já trabalhava, a exemplo do pai, como pedreiro.

15 Agradecemos a Marco Antonio Leite Brandão por essa informação.
} 


\section{Referências}

BARBOSA, C. Glossário do trabalho agrícola e profissões. São Paulo: Secretaria da Agricultura, Indústria e Comércio do Estado de São Paulo, 1943.

BASSANEZI, M. S. B.; FRANCISCO, P. S. B. Estado de São Paulo. Estatística Agrícola e Zootécnica, 1904-1905. Campinas: Nepo/ Unicamp, 2003 (CD-ROM).

BASSANEZI, M. S. B. Fazenda de Santa Gertrudes - uma abordagem quantitativa das relações de trabalho em uma propriedade rural paulista, 1895-1930. Tese (Doutorado). Rio Claro: Unesp, 1974.

. (Org.). São Paulo do passado - dados demográficos. Campinas: Nepo/ Unicamp, 2000 (CD-ROM).

CAMARGO, J. F. Crescimento da população no Estado de São Paulo e seus aspectos econômicos: ensaios sobre a relação entre demografia e a economia. Boletim da FFLCH/USP, São Paulo (3 vols.), 1952.

JUNQUEIRA, M. P. São Carlos em tempos de epidemia: imigração, saúde pública e urbanização (1877-1900). Tese (Doutorado). Araraquara: FCL-Unesp, 2004.

KLEIN, H. A imigração espanhola no Brasil. São Paulo: Editora Sumaré, 1994.

MATTOS, H. Das cores do silêncio: os significados da liberdade no Sudeste escravista - Brasil, séc. XIX. Rio de Janeiro: Nova Fronteira, 1998.

MONSMA, K. Symbolic conflicts, deadly consequences: fights between italians and blacks in western São Paulo, 1888-1914. Journal of Social History, 2006.

MONSMA, K.; TRUZZI, O.; CONCEIÇÃO, $S$. Solidariedade étnica, poder local e banditismo: uma quadrilha calabresa no oeste paulista, 1895-1898. Revista Brasileira de Ciências Sociais, São Paulo, v. 18, n. 53, p. 71-96, 2003.

PALMA, R. O perfil étnico-racial dos trabalhadores nos latifúndios cafeeiros de São Carlos em 1907 (trabalho de conclusão de curso). São Carlos: UFSCar e Fapesp, 2007.
RIBEIRO, M. A. R. História sem fim... Inventário da saúde pública. São Paulo: Editora Unesp, 1993.

SÃO PAULO (Estado). Decreto n. 181, de 24 de janeiro de 1890.

Decreto n. 1.533, de 23 de novembro de 1907.

Lei n. 1.038, de 19 de dezembro

de 1906

de 1907.

Lei n. 1.103, de 26 de novembro

Relatório da Secretaria de Agricultura, Commercio e Obras Públicas de 1894. São Paulo: Leroy King Typographia, 1895.

Relatório apresentado ao Exmo.

Sr. Presidente da Província de São Paulo pela Comissão Central de Estatística. São Paulo: Leroy King Typ., 1888.

Directoria do Serviço Sanitário.

Annuario Demographico: secção de Estatistica Demographo-sanitaria 1905. São Paulo: Typ. do Diário Oficial, 1906.

Directoria do Serviço Sanitário.

Annuario Demographico: secção de Estatistica Demographo-sanitaria 1906. São Paulo: Typ. Brasil de Rothichild \& Co., 1907.

Directoria do Serviço Sanitário.

Annuario Demographico: secção de Estatistica Demographo-sanitaria 1907. São Paulo: Typ. do Diário Oficial, 1908.

RECENSEAMENTO de São Carlos de 1907. São Carlos, 1907 (manuscrito).

TELAROLLI, Jr., R. Assistência sanitária e condições de saúde na zona rural paulista na Primeira República. Revista Brasileira de Estudos de População, v. 14, n. 1/2, p. 3-17, 1997.

TRUZZI, O. Café e indústria - São Carlos, 1850-1950. 3ạ. ed. São Paulo e São Carlos: Imprensa Oficial do Estado de São Paulo e EdUFSCar, 2007a. 
. Italianos no altar: padrões nup-

ciais no início da imigração em massa: São

Carlos (SP), 1880-1900. In: XXIV SIMPÓSIO

NACIONAL DE HISTÓRIA. Anais... São Le-

opoldo: ANPUH/Unisinos, 2007b.
(Org.). Fontes estatístico-nomi-

nativas da propriedade rural em São Carlos, 1873-1940. São Carlos: EdUFSCar, 2004.

VANGELISTA, C. Os braços da lavoura.

São Paulo: Hucitec, 1991.

\section{Resumen}

Población, grupos étnico-raciales y economía cafetera: São Carlos, 1907

En São Carlos, la formación de una población establecida se inició aún en la primera mitad del siglo XIX, con las primeras haciendas mantenidas por el trabajo esclavo. En 1884, con la llegada de la ferrovía, el municipio se insertó definitivamente en la vigorosa economía cafetera paulista. São Carlos acompañó así la transición de una economía tocada por el trabajo esclavo a otra en la que predominaban los colonos libres de origen europeo, sobre todo italiano. Menos de dos décadas después de la abolición de la esclavitud, la composición racial de la población se modificó significativamente, gracias a la gran afluencia de inmigrantes y, probablemente también, aunque en menor grado, a la salida de ex-esclavos del municipio. Este aporte diversificado se evidenció en el relevamiento censal realizado en el municipio en 1907, que abarcó la compilación de informaciones variadas referentes a 38.642 individuos que entonces lo habitaban. Este trabajo busca analizar y discutir las características demográficas y la inserción social de diferentes grupos étnico-raciales presentes en la población de São Carlos en esa época. Su relevancia deriva también de la ausencia de relevamientos poblacionales en el período en cuestión, dadas las conocidas deficiencias del censo de 1890 y 1900 y el largo período de 34 años de intermitencia entre el relevamiento poblacional de la provincia de San Pablo de 1886 y el censo nacional de 1920, éste más confiable, sin embargo omiso en cuanto al color de los individuos.

Palabras-clave: Población. Inmigrantes. Negros. Economía cafetera. São Carlos (San Pablo). Discriminación.

\section{Abstract}

Population, ethnic groups and the coffee industry: São Carlos, Brazil, 1907

The formation of the population of the city of São Carlos, in the south-central region of the Brazilian State of São Paulo, began in the first half of the 19th century with the first plantations operated by slave labor. In 1884, with the arrival of the railroad, the municipality became solidly and permanently integrated into the overall economy of the state. São Carlos thus kept up with the state's transition from an economy based on slave labor to one where free immigrant settlers of European origin, especially Italian, became the rule. Less than two decades after the abolition of slavery in Brazil, the racial composition of the population had changed significantly due to the great influx of immigrants and, probably, in addition, to the departure from the municipality of many former black slaves. This rapid change can be seen in the data from the federal census carried out in 1907, which compiled the diversified information referring to 38,642 individuals who then inhabited São Carlos. This present analysis discusses the demographic characteristics and social inclusion of different ethnic groups in the city's population during that period. Its importance also results from the absence of demographic data from the period in question, related to the recognized shortcomings of the censuses of 1890 and 1900 and the long period of 34 years between the demographic measurement in 
what was then the Province of São Paulo, in 1886, and the national census of 1920 . The 1920 Census is much more reliable, but nevertheless negligent in terms of the color of individuals.

Keywords: Population. Immigrants. Black population. Coffee industry. São Carlos (State of São Paulo). Discrimination.

Recebido para publicação em 08/12/2008. Aceito para publicação em 10/07/2009. 